\title{
COVID-19 and Sustainable Energy Development: Agendas for Future Research
}

\author{
KeVIN Lo* \\ Department of Geography, Hong Kong Baptist University, Kowloon Tong, Hong Kong
}

\begin{abstract}
The COVID-19 pandemic is having a massive impact on and may fundamentally change the pathways and trajectories of sustainable energy development. This article examines the impact of COVID-19 on Asia's sustainable energy development and proposes agendas for future energy research in response to the pandemic. The review and research agendas are oriented towards achieving the Sustainable Development Goal 7 (SDG 7), ensuring access to affordable, reliable, sustainable and modern energy for all. The following three key questions need to be addressed by researchers: (1) In what ways does COVID-19 make sustainable energy development more important than ever? (2) What are the short- and long-term effects of COVID-19 on sustainable energy development? (3) How can responses to COVID-19 meet the objectives of sustainable energy development?
\end{abstract}

Keywords: sustainable energy development, COVID-19, pandemic, Asia

\section{INTRODUCTION}

The COVID-19 pandemic began in Asia and has spread very widely and rapidly throughout the continent, developing into an unprecedentedly catastrophic health, economic, and humanitarian crisis. As governments scramble to fight the pandemic through quarantine, travel and trade restrictions, and lockdown measures, turmoil and disruption across all economic sectors are experienced [1]. Home to the majority of the world's population and accounting for nearly $50 \%$ of the global total energy production and consumption [2], the experience of Asia is fundamental to the sustainable energy development of the world. This article examines the impact of COVID-19 on sustainable energy development in Asia and suggests research agendas for energy studies in this new context. Sustainable energy development in this article is defined with reference to the United Nations Sustainable Development Goals 7 (SDG 7): to ensure access to affordable, reliable, sustainable and modern energy for all. As such, two key elements of sustainable energy development are recognized: (1) clean and sustainable energy and (2) accessible and affordable energy.

*Corresponding author: lokevin@hkbu.edu.hk

Received: 15 Aug 2020 Accepted: 15 Aug 2020 Published: 15 Aug 2020

Journal of Asian Energy Studies (2020), Vol 4, 20-25, doi:10.24112/jaes.040003 


\section{TAKing Stock: Sustainable Energy deVelopment in Asia before the PAN- DEMIC}

Energy systems need to be less polluting and more sustainable to avoid or to mitigate environmental health problems such as air pollution, anthropogenic climate change, and resource depletion. Energy is also an essential tool that improves the quality of life and drives socio-economic development, especially in marginalized and vulnerable communities.

Prior to the pandemic, sustainable energy transition was undergoing an increased momentum in Asia, although the pace was not yet fast enough to avoid dangerous climate change $[3,4]$. By the end of 2019, more solar photovoltaics, wind power, hydropower, and biopower capacities had been installed across Asia than in any other continent. China has become the global leader in renewable energy deployment, largely driven by effective and timely policy interventions [5-9]. A significant rise in renewable energy has also been recorded in other places in Asia such as India, Bangladesh, Japan, South Korea, and Southeast Asia [10-14]. Energy efficiency, while receiving much less attention, has also been improving across Asia [15-18].

Asia was also making strong but uneven progress in making energy accessible and affordable before the pandemic [19-21]. Between 2010 and 2018, around 800 million people gained access to electricity worldwide, $80 \%$ of which were residing in Asia. Meanwhile, access to electricity in developing countries in Asia has reached $94 \%$. However, affordability is a very different issue from accessibility. In fact, the shift from traditional energy to electricity and clean fuels may increase energy expenditure $[22,23]$. Progress in the access to clean cooking has been slowed, with 1.7 billion people ( $43 \%$ of the population) in Asia still relying on traditional biomass, coal, or kerosene in 2018.

\section{Agendas for Future Research}

The COVID-19 pandemic creates challenges, opportunities, and above all uncertainty over the future of sustainable energy development. It also opens up many new research opportunities for energy scholars who seek to make a difference through their scholarship. First, the pandemic forcefully underscores the importance of sustainable energy development. The link between energy and the prevention and treatment of COVID-19 is obvious-health facilities need reliable energy supply for their medical equipment and services such as ventilators and sterilization [24]. Furthermore, at the individual or household level, the imposition of lockdown measures means an increased demand for residential energy consumption $[25,26]$. Failing to provide cheap and reliable energy can create severe hardship for the marginalized population, as vividly illustrated in the experience of India [24]. The pandemic has exposed or magnified the problem of global inequalities in the access to basic energy services [27]. Improving energy access and affordability is more important and pressing than ever.

The pandemic also provides new insights of the importance of clean energy. There is mounting evidence that exposure to air pollution has a direct impact on COVID-19 infection and mortality $[28,29]$. This is not surprising, as the association between pollution and health is well established [30]. On the other hand, there is strong evidence showing that the pandemic, and particularly the lockdown measures, are having a significant impact on reducing air pollution [31,32]. Understanding how air pollution declines from COVID-19 is important because it can provide important evidence regarding the health benefits of sustainable energy development.

Second, the impact of the COVID-19 pandemic on sustainable energy development in Asia needs to be better understood. The pandemic has a substantial impact on global energy investment owing to supply chain disruptions, construction delays, reduction in energy demand, and financial 
challenges. To certain extent, the impact on renewable energy is not as strong as fossil energy owing to the low operating costs of renewables-based generation. Thus, this reduction in energy demand has resulted in renewables making up a larger share of the power supply. Furthermore, much of the progress on improving energy accessibility in Asia has been made through collaborations between governments and donors. However, the COVID-19 pandemic may shift the government focus or reduce its ability to implement energy access projects. It is therefore very important for academics to continue to champion the necessity of universal energy access and suggests areas of improvement.

Understanding the longer-term impact of the pandemic on sustainable energy development is even more difficult. From an energy production perspective, the impact of COVID-19 depends on how the economy recovers, and particularly on the actions of the government with regard to the economic recovery policies that are beginning to take form in many countries. According to the International Energy Agency [33], "the pandemic has the potential to change the priority of government policies and budgets, developers' investment decisions, and the availability of financing through 2025 and beyond". Previous experience, such as that during the global financial crisis, suggests that the focus on economic recovery means that environmental and sustainability concerns typically become secondary [34]. There are now serious concerns that governments may roll-back some clean energy policies or even reintroduce support for fossil fuel industries in order to achieve a faster economic recovery [3]. For example, China may relax its strict coal-fired power plant permitting system, even though by doing so it would substantially increase its carbon emissions.

The long-term impact of the pandemic on energy consumption is even less understood. The literature has long recognized that disasters have a tendency to catalyze the processes of social change [35]. Therefore, despite the relentless effort by the government and companies encouraging consumers to get back to "normal", it is possible that some fundamental changes in social practices are coming, which may have long-term impact on energy consumption. One example is the virtual revolution and de-globalization which, driven by travel bans around the world, could permanently change mobility patterns and shrink the demand for transportation [36]. The transport sector has long been a very large energy sector in Asia and a prime driver of carbon emissions [37-39]. Therefore, how the pandemic changes social practices and the implications of energy consumption should be studied carefully.

Third, research is urgently needed to contribute to the formulation of responses to COVID-19 that can meet the objectives of sustainable energy development. There are calls for a new green deal claiming that investment in renewable energy can drive economic recovery [40]. However, recovery programs branded "green" need to be examined critically and carefully, as carbon-intensive energy development incompatible with climate emergency is often deceptively termed "green", "clean", and "sustainable" [41]. As such, a critical analysis of stimulus packages and recovery plans is needed to detect any contradiction between planned economic recovery and sustainable energy development. Furthermore, policy studies are needed to provide evidence-based support to formulate effective green and sustainable recovery strategies.

Responses to COVID-19 also need to take the issues of energy justice into account [42]. As lockdown measures continue, domestic energy consumption increases, which places more financial burden on households. Furthermore, COVID-19-driven unemployment has been a socially unequal phenomenon, particularly hard for people with precarious work and marginalized communities. As such, the issue of energy affordability among these vulnerable people and communities needs to be examined. There is a significant likelihood that COVID-19 may worsen energy poverty issues, as more people have lost their jobs or have been working less hours, and thus have found themselves under stronger financial burdens. Supportive policies, such as offering free electricity 
or reductions in electricity bills, may be needed for an extended period of time [43].

\section{CONCLUSION}

In summary, this article proposes three key areas of research that are important in achieving sustainable energy development in Asia in the context of COVID-19. First, academic attention is needed to (re)examine the importance of sustainable energy development. Second, studies are needed to identify the short- and long-term effects of the pandemic on sustainable energy development, such as detecting any emerging shifts in the politics of energy production by closely following national recovery plans and stimulus packages. Studies are also needed to examine the fundamental shifts in social behaviors with regard to energy consumption. Third, energy researchers should contribute to the formulation of responses to COVID-19 that meet the objectives of sustainable energy development, especially with reference to the most vulnerable communities.

\section{REFERENCES}

[1] Nicola M, Alsafi Z, Sohrabi C, Kerwan A, Al-Jabir A, Iosifidis C, Agha M, Agha R. The socio-economic implications of the coronavirus pandemic (COVID-19): A review. International Journal of Surgery 2020:78:185-193.

[2] REN21. Asia and the Pacific Renewable Energy Status Report. REN21 Secretariat, Paris, 2019.

[3] Steffen B, Egli F, Pahle M, Schmidt TS. Navigating the clean energy transition in the COVID-19 crisis. Joule 2020:4:1137-1141.

[4] Lo K. Asian energy challenges in the Asian century. Journal of Asian Energy Studies 2017:1:1-6.

[5] Andrews-Speed P, Zhang S. China as a low-carbon energy leader: Successes and limitations. Journal of Asian Energy Studies 2018:2:1-9.

[6] Lo K. Governing China's clean energy transition: Policy reforms, flexible implementation and the need for empirical investigation. Energies 2015:8:13255-13264.

[7] Lo K. A critical review of China's rapidly developing renewable energy and energy efficiency policies. Renewable and Sustainable Energy Reviews 2014:29:508-516.

[8] Lo K, Castán Broto V. Co-benefits, contradictions, and multi-level governance of low-carbon experimentation: Leveraging solar energy for sustainable development in China. Global Environmental Change 2019:59:101993.

[9] Mamat R, Sani MS, Khoerunnisa F, Kadarohman A. Target and demand for renewable energy across 10 ASEAN countries by 2040. The Electricity Journal 2019:32:106670.

[10] Dong Y, Shimada K. Evolution from the renewable portfolio standards to feed-in tariff for the deployment of renewable energy in Japan. Renewable Energy 2017:107:590-596.

[11] Kim S, Lee H, Kim H, Jang DH, Kim HJ, Hur J, Cho YS, Hur K. Improvement in policy and proactive interconnection procedure for renewable energy expansion in South Korea. Renewable and Sustainable Energy Reviews 2018:98:150-162.

[12] Mamat R, Sani M, Sudhakar K. Renewable energy in Southeast Asia: Policies and recommendations. Science of the Total Environment 2019:670:1095-1102.

[13] Liza ZA, Aktar H, Islam MR. Solar energy development and social sustainability: A case study on the Teknaf Solar Power Plant in Bangladesh. Journal of Asian Energy Studies 2020:4:1-8.

[14] Yenneti K, Day R. Procedural (in)justice in the implementation of solar energy: The case of Charanaka solar park, Gujarat, India. Energy Policy 2015:86:664:673.

[15] Lo K. Governing energy consumption in China: a comprehensive assessment of the energy conservation target responsibility system. Energy Transitions 2020:4:57-67. 
[16] Lo K, Li H, Wang M, Energy conservation in China's energy-intensive enterprises: An empirical study of the Ten-Thousand Enterprises Program. Energy for Sustainable Development 2015:27:105-111.

[17] Abbas SZ, Kousar A, Razzaq S, Saeed A, Alam M, Mahmood A. Energy management in South Asia. Energy Strategy Reviews 2018:21:25-34.

[18] Li H, Lo K, Wang M, Zhang P, Xue L. Industrial energy consumption in Northeast China under the revitalisation strategy: A Decomposition and policy analysis. Energies 2016:9:549.

[19] Palit D. Solar energy programs for rural electrification: Experiences and lessons from South Asia. Energy for Sustainable Development 2013:17:270-279.

[20] Palit D, Bandyopadhyay KR. Rural electricity access in South Asia: Is grid extension the remedy? A critical review. Renewable and Sustainable Energy Reviews 2016:60:1505-1515.

[21] Cameron C, Pachauri S, Rao ND, McCollum D, Rogelj J, Riahi K. Policy trade-offs between climate mitigation and clean cook-stove access in South Asia. Nature Energy 2016:1:15010.

[22] Sankhyayan P, Dasgupta S. 'Availability' and/or 'Affordability': What matters in household energy access in India? Energy Policy 2019:131:131-143.

[23] Lo K., Xue L, Wang M. Spatial restructuring through poverty alleviation resettlement in rural China. Journal of Rural Studies 2016:47:496-505.

[24] Castán Broto V, Kirshner J. Energy access is needed to maintain health during pandemics. Nature Energy 2020:5:419-421.

[25] Saadat S, Rawtani D, Hussain CM. Environmental perspective of COVID-19. Science of The Total Environment 2020:728:138870.

[26] Wang Q, Su M. A preliminary assessment of the impact of COVID-19 on environment-A case study of China. Science of the Total Environment 2020:728:138915.

[27] Brosemer K, Schelly C, Gagnon V, Arola KL, Pearce JM, Bessette D, Olabisi LS. The energy crises revealed by COVID: Intersections of Indigeneity, inequity, and health. Energy Research $\mathcal{E}$ Social Science 2020:68:101661.

[28] Yongjian Z, Jingu X, Fengming H, Liqing C. Association between short-term exposure to air pollution and COVID-19 infection: Evidence from China. Science of the Total Environment 2020:727:138704.

[29] Fattorini D, Regoli F. Role of the chronic air pollution levels in the Covid-19 outbreak risk in Italy. Environmental Pollution 2020:264:114732.

[30] Brunekreef B, Holgate ST. Air pollution and health. The Lancet 2002:360:1233-1242.

[31] Berman JD, Ebisu K. Changes in US air pollution during the COVID-19 pandemic. Science of the Total Environment 2020:739:139864.

[32] Muhammad S, Long X, Salman M. COVID-19 pandemic and environmental pollution: a blessing in disguise? Science of The Total Environment 2020:728:138820.

[33] International Energy Agency. Tracking clean energy progress. 2019. https:/ / www.iea.org/topics/tracking-clean-energy-progress

[34] Peters GP, Marland G, Le Quéré C, Boden T, Canadell JG, Raupach MR. Rapid growth in $\mathrm{CO}_{2}$ emissions after the 2008-2009 global financial crisis. Nature Climate Change 2012:2:2-4.

[35] Cohen MJ. Does the COVID-19 outbreak mark the onset of a sustainable consumption transition? Sustainability: Science, Practice and Policy 2020:16:1-3.

[36] Hepburn C, O'Callaghan B, Stern N, Stiglitz J, Zenghelis D. Will COVID-19 fiscal recovery packages accelerate or retard progress on climate change? Oxford Review of Economic Policy 2020. https://doi.org/10.1093/oxrep/graa015

[37] Lo K, Interested but unsure: Public attitudes toward electric vehicles in China. Electronic Green Journal 2013:36:1-12. 
[38] Li J, Lo K, Zhang P. Shopping mobility and travel carbon emissions among suburban residents: Lessons from Shenyang city, China. Journal of Spatial Science 2018:63:311-323.

[39] Timilsina GR, Shrestha A. Transport sector $\mathrm{CO}_{2}$ emissions growth in Asia: Underlying factors and policy options. Energy Policy 2009:37:4523-4539.

[40] Rosenbloom D, Markard J. A COVID-19 recovery for climate. Science 2020:368:447-447.

[41] Stephenson E, Doukas A, Shaw K. Greenwashing gas: Might a 'transition fuel' label legitimize carbon-intensive natural gas development? Energy Policy 2012:46:452-459.

[42] Jenkins K, McCauley D, Heffron R, Stephan H, Rehner R. Energy justice: a conceptual review. Energy Research \& Social Science 2016:11:174-182.

[43] Akrofi MM, Antwi SH. COVID-19 energy sector responses in Africa: A review of preliminary government interventions. Energy Research E Social Science 2020:68:101681.

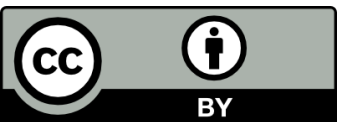

(C) The Author(s) 2020. This article is published under a Creative Commons Attribution (CC-BY) 4.0 International License. 